\title{
Yersinia Phages and Food Safety
}

\author{
Carlos G. Leon-Velarde ${ }^{1, \dagger}$, Jin Woo Jun ${ }^{2, \dagger}$ and Mikael Skurnik ${ }^{3,4, * \mathbb{D}}$ \\ 1 Agriculture and Food Laboratory, Laboratory Services Division, University of Guelph, \\ Guelph, ON N1H 8J7, Canada; cleonvel@uoguelph.ca \\ 2 Department of Aquaculture, Korea National College of Agriculture and Fisheries, Jeonju 54874, Korea; \\ advancewoo@snu.ac.kr \\ 3 Department of Bacteriology and Immunology, Medicum, Human Microbiome Research Program, Faculty of \\ Medicine, University of Helsinki, 00014 HY Helsinki, Finland \\ 4 Division of Clinical Microbiology, HUSLAB, Helsinki University Hospital, 00029 HUS Helsinki, Finland \\ * Correspondence: mikael.skurnik@helsinki.fi; Tel.: +358-2941-26464 \\ + These authors contributed equally to the work.
}

Received: 8 November 2019; Accepted: 26 November 2019; Published: 28 November 2019

\begin{abstract}
One of the human- and animal-pathogenic species in genus Yersinia is Yersinia enterocolitica, a food-borne zoonotic pathogen that causes enteric infections, mesenteric lymphadenitis, and sometimes sequelae such as reactive arthritis and erythema nodosum. Y. enterocolitica is able to proliferate at $4{ }^{\circ} \mathrm{C}$, making it dangerous if contaminated food products are stored under refrigeration. The most common source of Y. enterocolitica is raw pork meat. Microbiological detection of the bacteria from food products is hampered by its slow growth rate as other bacteria overgrow it. Bacteriophages can be exploited in several ways to increase food safety with regards to contamination by $Y$. enterocolitica. For example, Yersinia phages could be useful in keeping the contamination of food products under control, or, alternatively, the specificity of the phages could be exploited in developing rapid and sensitive diagnostic tools for the identification of the bacteria in food products. In this review, we will discuss the present state of the research on these topics.
\end{abstract}

Keywords: Yersinia enterocolitica; bacteriophage; application of Yersinia phages; food safety; tail fiber protein; magnetic separation; biocontrol

\section{Introduction}

The most numerous organisms on Earth are the viruses of bacteria, bacteriophages (phages for short), that are present in 10-fold excess to bacteria, their host cells [1]. The total number of phages has been estimated to be around $10^{31}$ particles [2]. The constant arms range between phages and their prey, the bacteria, has generated high diversity among the phages in nature [3]. Phage research has, during the last ten years, seen a renaissance after several decades' decline; the present interest focuses on genome and evolution research, on systems biology studies, and horizontal gene transfer. In addition, phages themselves are excellent tools in bacterial genetics, and phage-derived enzymes are indispensable tools in molecular biology. As the world is facing the threat of increasing antibiotic resistance, phage therapy, the 100-year-old remedy of bacterial infections practiced in the former Soviet Union and Russia, and also sporadically in Europe and the USA until the 1940's, has been seen as a possible solution. In phage therapy, lytic phages have been preferred since, after replicating itself, the phage kills its host bacteria and does not disrupt the normal microbiota [4]. In addition to curing bacterial infections, phages can also be used prophylactically to control bacterial pathogens in food production, having the benefit that phages do not damage the populations of beneficial bacteria present [5]. 


\section{Genus Yersinia and Diseases}

Yersinia pestis, Y. pseudotuberculosis, and Y. enterocolitica constitute the human pathogenic species in the genus Yersinia; the remaining of the altogether 17 species of these facultative anaerobic Gram-negative coccobacilli are considered environmental non-pathogens. Y. pestis is highly virulent and the notorious causative agent of the bubonic plague. The other two, Y. pseudotuberculosis, and $Y$. enterocolitica are less virulent and cause a globally important foodborne zoonotic disease, known as yersiniosis. The symptoms of yersiniosis usually initiate with fever and abdominal pain. The bacteria have a tropism to lymph nodes and often cause painful mesenteric lymphadenitis easily confused with appendicitis. The infections are oftentimes manifested by diarrhea that can even be bloody [6]. As sequelae, mainly in human leukocyte antigen B27 positive individuals, yersiniosis may induce reactive arthritis or erythema nodosum. The pathogenicity of all Yersinia species depends on many essential virulence factors encoded by genes located both on the $70 \mathrm{~kb}$ virulence plasmid and on the chromosome. Among the over 50 recognized O-serotypes of Y. enterocolitica, only a few (predominantly $\mathrm{O}: 3, \mathrm{O}: 5,27, \mathrm{O}: 8$, and $\mathrm{O}: 9)$ that carry the $70 \mathrm{~kb}$ virulence plasmid, are pathogenic [7], and are thereby, the major causative agents of yersiniosis [8]. While most Y. enterocolitica infections in humans are caused by consumption of raw or undercooked contaminated pork [8], rarely by contaminated raw milk or untreated water, the pathogen may also spread from person-to-person, or from infected animals or their feces [6].

Y. enterocolitica is considered an important zoonotic pathogen in developed countries, being the third most commonly reported in the European Union [9], and the cause of almost 117,000 illnesses and 35 deaths in the United States every year [6]. In Finland, with a population of ca. 5.5 million people, the reported number of yersiniosis cases is 500-600 annually (http://urn.fi/URN:ISBN:978-952-302-978-1). Furthermore, Y. pseudotuberculosis has recently caused several large outbreaks due to contaminated carrots and iceberg lettuce [10].

\section{Yersinia enterocolitica Bacteriophages}

Bacteriophages infecting Y. enterocolitica have been found to belong to all three-tailed families of the order Caudovirales, the Myoviridae (contractile tails), Siphoviridae (long, non-contractile tails), and Podoviridae (short, non-contractile tails). Initial studies from 1967 to 1987 were restricted to electron microscopy observations accompanied by some host range information of lytic phages used for typing Y. enterocolitica [11-22]. Further reports focused on the morphology and host range [23-29] interspersed with a more thorough characterization of several other $Y$. enterocolitica phages reporting on their genome sequence, proteome, morphology, host range, receptor specificity, and the identification of the receptor binding proteins (RBPs) involved in host recognition (Table 1).

Table 1. Bacteriophages infecting Yersinia enterocolitica.

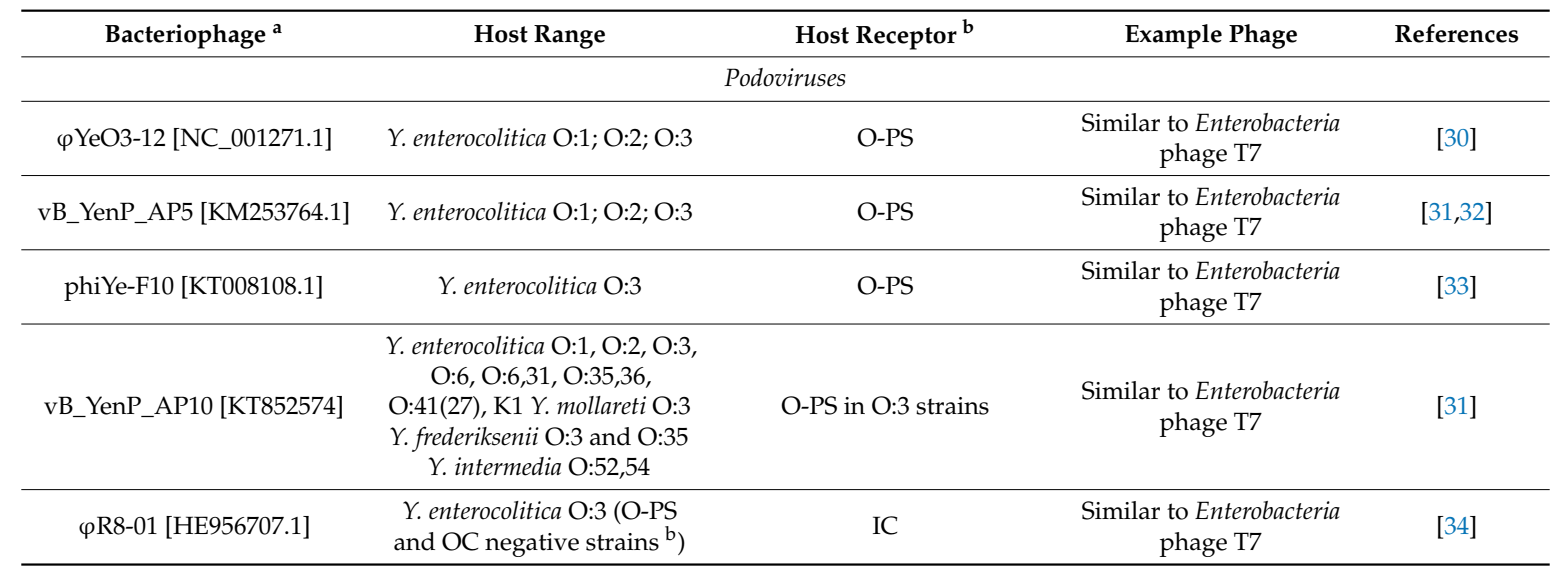


Table 1. Cont.

\begin{tabular}{|c|c|c|c|c|}
\hline Bacteriophage $^{\text {a }}$ & Host Range & Host Receptor ${ }^{b}$ & Example Phage & References \\
\hline \multicolumn{5}{|c|}{ Podoviruses } \\
\hline$\varphi 80-18$ [HE956710.1] & Y. enterocolitica O:8, O:7,8 & O-PS & $\begin{array}{c}\text { Similar to Enterobacteria } \\
\text { phage } \mathrm{T} 7\end{array}$ & [35] \\
\hline $\begin{array}{l}\text { fPS Group } 1 \text { phages (11 } \\
\text { closely related phages with } \\
\text { phage fPS-7 [LT961840] as } \\
\text { type species) }\end{array}$ & Y. enterocolitica O:3 & O-PS & $\begin{array}{c}\text { Similar to Enterobacteria } \\
\text { phage } \mathrm{T} 7\end{array}$ & [28] \\
\hline $\begin{array}{c}\text { fPS Group } 2 \text { phages (fPS- } 53 \text {, } \\
\text { fPS- } 85, \text { fPS- } 89 \text { fPS- } 54-\text { ocr } \\
\text { with phage fPS-53 } \\
\text { [LT962379] as type species) }\end{array}$ & Y. enterocolitica O:3 & $\begin{array}{l}\text { OC could be the receptor for } \\
\text { fPS- } 53 \text {, fPS- } 85 \text {, and fPS- } 89 ; \\
\text { probable Omp as a receptor } \\
\text { for fPS- } 54 \text {-ocr }\end{array}$ & $\begin{array}{c}\text { Similar to Enterobacteria } \\
\text { phage } \mathrm{T} 7\end{array}$ & [28] \\
\hline $\begin{array}{l}\text { fPS Group } 3 \text { phages (phage } \\
\text { fPS-59 [LT961845]) }\end{array}$ & Y. enterocolitica O:3 & O-PS & $\begin{array}{c}\text { Similar to Enterobacteria } \\
\text { phage } \mathrm{T} 7\end{array}$ & [28] \\
\hline \multicolumn{5}{|c|}{ Siphoviruses } \\
\hline$\varphi \mathrm{R} 2-01$ [HE956708.1] & $\begin{array}{l}\text { Y. enterocolitica } \mathrm{O}: 8 \text { (O-PS } \\
\left.\text { negative strains }{ }^{\mathrm{b}}\right) .\end{array}$ & BtuB & $\begin{array}{l}\text { Similar to Enterobacteria } \\
\text { phageT5 }\end{array}$ & [37] \\
\hline PY-54 [NC_005069.1] & $\begin{array}{c}\text { Y. enterocolitica O:5, O:5,27, } \\
\text { Some Y. enterocolitica Biotype } \\
\text { 1A strains }\end{array}$ & Unknown & Similar to phage $\lambda$ & [38-40] \\
\hline \multicolumn{5}{|c|}{ Myoviruses } \\
\hline PY-100 [AM076770.1] & $\begin{array}{c}\text { Y. enterocolitica O:3, O:5,27, } \\
\text { O:8, O:9, some Biotype } 1 \mathrm{~A} \\
\text { strains, and some } \\
\text { untypeable strains Y. pestis Y. } \\
\text { pseudotuberculosis Y. } \\
\text { intermedia Y. kristensenii Y. } \\
\text { frederiksenii Y. rohdei } Y . \\
\text { mollareti }\end{array}$ & Unknown & $\begin{array}{l}\text { Similar to phiPLPE-like } \\
\text { phages (Dwarf } \\
\text { Myoviruses) }\end{array}$ & [41-43] \\
\hline$\varphi$ R1-RT [HE956709.1] & $\begin{array}{l}\text { Y. enterocolitica O:1, O:2, O:3, } \\
\text { O:5, O:5,27, O:6, O:7,8, O:9 }\end{array}$ & OmpF and IC of LPS & $\begin{array}{c}\text { Similar to Enterobacteria } \\
\text { phage } \mathrm{T} 4\end{array}$ & [44] \\
\hline vB_YenM_TG1 [KP202158.1] & $\begin{array}{l}\text { Y. enterocolitica O:1, O:2, O:3, } \\
\text { O:5, O:5,27, O:6, O:7,8, O:9 }\end{array}$ & OmpF and IC of LPS & $\begin{array}{c}\text { Similar to Enterobacteria } \\
\text { phage } \mathrm{T} 4\end{array}$ & [44] \\
\hline fHe-Yen9-01 [KY593455] & $\begin{array}{c}\text { Broad host range infecting } \\
61.3 \%(65 / 106) \text { of the Yersinia } \\
\text { strains tested } 65.4 \% \text { (53/81) } \\
\text { of the Y. enterocolitica strains } \\
\text { tested }\end{array}$ & Unknown & $\begin{array}{c}\text { Similar to Enterobacteria } \\
\text { phage } \mathrm{T} 4\end{array}$ & [36] \\
\hline
\end{tabular}

a GenBank accession numbers are listed in brackets; ${ }^{b}$ LPS, a component found on the outer membrane of Gram-negative bacteria, is in Y. enterocolitica O:3 composed of lipid A (LA), inner core (IC), outer core (OC), and O-specific Polysaccharide (O-PS) [42].

\subsection{Podoviruses}

With the exception of phage $\varphi 80-18$ [35], which utilizes the O-PS of Yersinia enterocolitica O:8 and O:7,8 and other strains that carry the O:8 moiety [35,45], all other Podoviruses that have been characterized, have been isolated using $Y$. enterocolitica O:3 strains as a host since it is the most predominant serotype involved in human yersiniosis. For example, in the European Union, the serotype O:3 accounts for over $89 \%$ of $Y$. enterocolitica infections followed by serotypes O:9 (7\%), O:5,27 $(2 \%)$, and O:8 (2\%) [46].

Among these, the lytic phage $\varphi$ YeO3-12 isolated from raw sewage in Finland is perhaps the most thoroughly studied, displaying a marked specificity for $Y$. enterocolitica O:3 [30,47,48]. Likewise, the lytic phage vB_YenP_AP5 isolated from raw sewage in Canada with a high degree of sequence similarity to $\varphi \mathrm{YeO} 3-12$ also exhibits a host range restricted to $Y$. enterocolitica O:3 [31,32]. Both of 
these phages utilize the O-PS of the LPS as the phage receptor $[30,32,48]$, which is composed of a homopolymer of 6-deoxy-L-altropyranose [49-51]. These two phages also show activity against strains, which also contain 6-deoxy-L-altropyranose in their LPS such as Y. enterocolitica O:1 and O:2, as well as to $Y$. mollareti O:3 and Y. frederiksenii O:3. Specificity for serotype O:3 strains using the OP-S as a receptor has also been reported for the recently described lytic phage phiYe-F10 [33] and for several other phages described as the fPS Group 1 phage, and fPS Group 3 phages [28]. In contrast, fPS Group 2 phages utilize the OC of the LPS as the phage receptor [28], and phage $\varphi$ R8-01 utilizes the IC of the LPS [34]. Thus, their host range is narrower, and they do not infect $Y$. enterocolitica O:3 with a complete LPS chemotype [52]. Notably, for the majority of these phages, the phage tail associated receptor binding proteins (RBP) necessary for host cell recognition, adsorption, and initiation of infection have been identified. For example in phage $\varphi$ YeO3-12, the tail fiber protein derived from the product of gene 17 of 645 amino acid (aa) residues is considered the major host range determinant, since the replacement of the homologous gene in bacteriophage T3 with that of $\varphi$ YeO3-12 was sufficient to turn Enterobacteria phage T3 into a Y. enterocolitica infecting phage [30].

\subsection{Siphoviruses}

There are only two Siphoviruses reported to infect Y. enterocolitica. The most thoroughly characterized is the temperate phage PY54 that was isolated in Germany from farm manure. PY54 exhibits a host range with specificity for Y. enterocolitica of serotypes O:5, for the epidemiologically significant strains of serotype O:5,27 and some non-pathogenic strains of Biotype 1A [27,39,40,45]. Regrettably, the host cell receptor(s) of phage PY54 have yet to be identified. Moreover, the identification of the RBPs of phage PY54 is complicated by homology searches providing a sequence identity to numerous prophage genomes sequenced within bacterial genomes and having low similarity to other phage genomes. Still, in silico analysis of the PY54 genome reveals two probable RBP genes, ORF22 and ORF25. Since the location of the probable RBP genes on the PY54 genome must be similar to the location of the related genes on the genomes of other lambdoid phages, alignment with the genome of Enterobacteria phage $\lambda$ [NC_001416.1], suggests that ORF22 and ORF25 likely correspond to the phage $\lambda$ host specificity protein J and side tail fiber (stf) protein, respectively $[40,53,54]$. In phage $\lambda$, the stf protein plays a role in primary attachment of the virion to the host, binding transiently until the tail tip, composed of the host specificity protein J, interacts irreversibly inducing structural changes in the tail, leading to viral DNA injection into the cell $[55,56]$. It is unclear, however, if the putative stf protein of PY54 is required since the corresponding protein in phage $\lambda$ is not essential for adsorption to its receptor, the bacterial maltose pore protein LamB $[57,58]$.

The other Siphovirus is Yersinia phage $\varphi$ R2-01, isolated in Finland using an O-PS negative LPS mutant derived from $Y$. enterocolitica $\mathrm{O}: 8$. We are in the process of characterizing its host range and $\mathrm{RBP}(\mathrm{s})$ and have identified BtuB as its receptor [37]. The phage $\varphi \mathrm{R} 2-01$ genome presents a gene organization similar to that of Enterobacteria phage T5, which facilitates the identification of its putative RBPs by gene synteny and protein homology searches. In phage $\mathrm{T} 5$, the non-contractile tail contains a collar structure that also serves as a baseplate for three L-shaped fibers (pb1) and a cone-shaped tip structure (pb5) ending in a central tail fiber [59-61]. In the phage $\varphi$ R2-01, gene 123 corresponds to the terminal end of the L-shaped fiber (pb1), and the product of gene 144 is homologous to pb5 of phage T5, which binds to the E. coli Omp ferrichrome transporter FhuA [62,63].

\subsection{Myoviruses}

Among the Y. enterocolitica phages, the lytic phage PY100 isolated from farm manure in Germany displays the widest host range reported [64]. PY100 infects strains from the three human pathogenic species Y. pestis, Y. pseudotuberculosis, and Y. enterocolitica, as well as other Yersinia spp. including Y. intermedia, Y. kristensenii, Y. frederiksenii, and Y. mollareti. Among the Y. enterocolitica that are susceptible are strains belonging to serotypes O:3, O:5,27, O:8, O:9, several biotype 1A strains, and several untypeable strains [64]. PY100 has a small genome of linear dsDNA of 50,291 bp, in comparison 
to Enterobacteria phage T4, which has a genome that is $168 \mathrm{~kb}$ in size. More importantly, however, due to its exceptionally broad host range, PY100 is a candidate for use as a biocontrol agent [65].

In contrast, the extensively studied phage $\varphi$ R1-37 is the largest $Y$. enterocolitica phage that has been reported. Also, isolated from raw sewage in Finland, $\varphi$ R1-37 has a $262 \mathrm{~kb}$ genome in size with extended terminal redundancy and resembles morphologically Pseudomonas aeruginosa phage $\varphi \mathrm{KZ}$, which is considered one of the largest bacteriophages $[41,66,67]$. Phage $\varphi$ R1-37 has no overall DNA sequence identity with any other phage genome and codes for 366 putative gene products, most of which are unrelated to any known protein in databases, indicating that close relatives have not been characterized. Phage $\varphi$ R1-37 was isolated based on its ability to infect an O-PS negative derivative of Y. enterocolitica $\mathrm{O}: 3$ [41,68], and the $\varphi$ R1-37 host receptor has been determined to be the OC hexasaccharide $[42,43]$. Phage $\varphi$ R1-37 displays a broad specificity showing virulence for $Y$. enterocolitica O:1, O:3, O:5, O:5,27, $\mathrm{O}: 6, \mathrm{O}: 6,31, \mathrm{O}: 9, \mathrm{O}: 21, \mathrm{O}: 25,26,44, \mathrm{O}: 41,43, \mathrm{O}: 41(27) 43$, and O:50 [41,43,69]. The phage receptor however, is also present in the OC of $Y$. intermedia O:52,54, and in the O-PS of $Y$. similis, which were also sensitive to $\varphi$ R1-37 [41,43,69]. Since the long-tail fiber genetic locus is highly conserved among the Myoviridae [70], the $\varphi$ R1-37 genome was inspected to locate genes encoding probable tail fiber proteins. The gene 8298 was identified as coding for a probable RBP homologous to the phage T4 long-tail fiber protein Gp37 involved in host recognition, and the adjacent gene g297 presents homology to Gp38 from phage T4, a tail fiber assembly protein. Our unpublished results have confirmed that Gp298 and its chaperone Gp297 are involved in host recognition [71].

Next are Yersinia phage $\varphi$ R1-RT and vB_YenM_TG1, which are closely related Myoviruses with a T4-like gene arrangement isolated in Finland and Canada, respectively [44]. Based on phylogenetic analyses of their whole genome sequences and large terminase subunit protein sequences, a genus named Tg1virus within the family Myoviridae was established with TG1 and $\varphi$ R1-RT as member species by the International Committee on Taxonomy of Viruses (ICTV) [72]. These lytic bacteriophages exhibit a host range restricted to $Y$. enterocolitica, displaying virulence for strains of serotypes O:1, $\mathrm{O}: 2, \mathrm{O}: 3, \mathrm{O}: 5, \mathrm{O}: 6, \mathrm{O}: 5,27, \mathrm{O}: 7,8, \mathrm{O}: 9$, and some strains of serotype O:6,30 and O:6,31 at or below $25^{\circ} \mathrm{C}$. Phage adsorption analyses of LPS and ompF mutants demonstrated that the phage RBPs Gp12 (short-tail fiber) and Gp37 (long-tail fiber) use the LPS inner core heptosyl residues and the outer membrane protein $\mathrm{OmpF}$ as phage receptors, with the later acting as the primary host determinant. Analysis of RNA-sequencing data demonstrated that under different growth temperatures, there is an inverse correlation between the expression of ompF in the host and temperature. Consistently, quantitative proteomics data demonstrated that $\mathrm{OmpF}$ is maximally expressed at $4{ }^{\circ} \mathrm{C}$, displays abundance at $22{ }^{\circ} \mathrm{C}$, but is minimally expressed at $37^{\circ} \mathrm{C}$ [44]. Collectively, these findings suggest the temperature-dependent infection of these phages is due to the strong repression of OmpF at $37^{\circ} \mathrm{C}$. Such an observation highlights the importance of thoroughly understanding phage-host cell interactions when considering the use of phages for biocontrol or diagnostic applications.

More recently, Jun et al. [36] reported the isolation of three additional Myoviruses (fHe-Yen9-01, fHe-Yen9-02, and fHe-Yen9-03) from sewage in Finland capable of infecting Y. enterocolitica. Among these, phage fHe-Yen9-01 was characterized as it had the broadest host range lysing 65 of 106 (61.3\%) of Yersinia strains tested and formed plaques on 53/81 (65.4\%) of the Y. enterocolitica strains tested, including epidemiologically significant strains of serotype O:3, O:5,27, and O:9. The phage genome has a T4-like gene organization and is closely related to the aforementioned Yersinia phages $\varphi$ R1-RT and vB_YenM_TG1 [36]. In addition, fHe-Yen9-01 was shown to be stable across a pH range of 5-9 and did not contain genes related to lysogeny or associated with undesirable virulence factors that might preclude their use as biocontrol agents [36]. 


\section{Applications of Yersinia Bacteriophages for Food Safety}

At present, studies on the application of $Y$. enterocolitica phages for food safety are focused on expanding the search for phages with the potential for use in diagnostics [31], or as biocontrol agents to reduce or eliminate this foodborne pathogen from domestic animals or from potentially contaminated foods and fomites $[36,64,65]$.

\subsection{Biocontrol of Y. enterocolitica}

Despite the technological development in food processing to control foodborne pathogens, food safety has been continuously an issue in the food industry. As a major cause of foodborne outbreaks, microbial contamination has received much public interest. We are now encountering changing lifestyles that could make the food safety issue complicated: the abundance of RTE foods and the growing interest of the public toward exotic foods. Considerable progress in phage development for the food industry has been made in the last decade, ever since the US-FDA approved the first phage-based product for use in foods in 2006 [73].

In many cases, foodborne pathogens originating from raw materials can cause the contamination of food products. In addition, their contamination can be caused by the manufacture or processing of the product [4]. For the successful application of phages in food safety, various factors should be taken into consideration, which have been reviewed extensively [74-79]. Mainly, the phages should be strongly lytic, stable within the environment they are to be used in, and have a broad host range (alone or in a cocktail) encompassing epidemiologically significant strains. Moreover, the genomes of these phages should not contain any undesirable laterally transferable genes that are related to bacterial toxins, pathogenicity, antibiotic resistance, and or lysogeny. In addition, phages have some advantages regarding their commercialization. First, phages are natural [74], and this makes them very attractive since this is one of the top priorities in the food industry. It is well known that many consumers show a preference for natural or minimally processed products. The second advantage is that no known harmful effects have been reported to date with the use of phages [74]. Therefore, there are no reasons to restrict their application, and as such, these phages can be utilized for each stage along the 'farm to fork' continuum. Lastly, phages do not produce any adverse organoleptic changes; they do not affect the taste, texture, smell, or color of food [74].

In a recent study, we assessed the efficacy of Yersinia phages against $Y$. enterocolitica in food products and on kitchen utensils [36]. Artificial contamination models were generated to mimic situations that are considered to be sources of yersiniosis. Raw pork, ready-to-eat (RTE) pork, and milk were artificially contaminated with $Y$. enterocolitica to reach an approximate bacterial inoculation level of $10^{3} \mathrm{CFU} / \mathrm{g}$ or $\mathrm{mL}$. Thereafter, the food samples were treated with phage fHe-Yen9-01 at a concentration of $10^{8} \mathrm{pfu} / \mathrm{g}$ or $\mathrm{mL}$ and maintained at appropriate conditions (raw pork, $4{ }^{\circ} \mathrm{C}$ for $72 \mathrm{~h}$; RTE pork, $26^{\circ} \mathrm{C}$ for $12 \mathrm{~h}$; milk, $4^{\circ} \mathrm{C}$ for $72 \mathrm{~h}$ ). It was found that phage treatment prevented bacterial growth throughout the experiments, with counts decreasing by 1-3 logs on food samples. In addition, we designed kitchen utensils, such as wooden and plastic cutting boards and knives, and artificial hands, which were then artificially contaminated with Y. enterocolitica, and then treated with phage $\left(10^{8} \mathrm{pfu} / \mathrm{cm}^{2}\right.$ or $\mathrm{mL}$ ). The bacterial counts decreased by $1-2 \log$ from the original levels of ca $10^{4} \mathrm{CFU} / \mathrm{cm}^{2}$ or mL. This is similar to results obtained by Orquera et al., 2012, who reported a 2- $\log _{10}$ unit decrease in Y. enterocolitica from inoculated raw meat at $4{ }^{\circ} \mathrm{C}$ after $48 \mathrm{~h}$ with the broad host range Yersinia phage PY100 [67]. Altogether, these studies reveal that phages can be applied for the control of Y. enterocolitica in foods and on kitchen utensils, and serve as a model for the prevention of other, more serious foodborne infections. 


\subsection{Phage RBPs for Use in Diagnostics}

Although numerous methods using bacteriophages for the rapid detection of food-borne pathogens have been proposed [80-91], analogous approaches are yet to be considered for the detection of pathogenic $Y$. enterocolitica from foods. These methods rely on native or genetically engineered phages for infection and lysis of target cells to measure detection of ATP release, detection of other bacterial cytoplasmic markers, measurement of impedance, or the activity or detection of reporter genes. However, since several phages with specificity for $Y$. enterocolitica serotypes of concern are now well characterized, the development of similar methods is feasible. Another potential approach is perhaps through the use of phage-derived adhesion proteins rather than whole phages, as demonstrated by the use of cell-wall-binding domains (CBDs) of bacteriophage endolysins for the detection of the Gram-positive foodborne pathogens such as Listeria monocytogenes, Bacillus cereus, and Clostridium perfringens [92-94]. However, the use of CBDs from endolysins derived from Y. enterocolitica may be limited due to the structural differences between the Gram-negative and Gram-positive cell walls, where in the latter, the peptidoglycan layer is readily accessible from outside the cell. Lastly, the RBPs of bacteriophages have also been proposed as ideal ligands for use in diagnostics since they are responsible for initial and specific interaction with host cell receptors.

Recently, we successfully produced soluble purified recombinant forms of correctly folded phage RBPs Gp17, Gp47, and Gp37, derived from Y. enterocolitica phages vB_YenP_AP5, $\varphi 80-18$, and vB_YenM_TG1, respectively, for use in diagnostics [31,44]. Analysis via confocal laser immunofluorescent microscopy confirmed the specific binding of purified recombinant forms of the RBPs Gp17, Gp47, and Gp37 to host cell surfaces (Figure 1), demonstrating a similar binding spectrum to the host range of the phages they were derived from based on the analysis of 165 Yersinia sp. strains [31,44]. In addition, to explore their potential use in biosensor applications, surface plasmon resonance (SPR) analyses of the interaction between these phage RBPs and Y. enterocolitica cells was possible following immobilization of the RBPs via an amine coupling procedure on a gold sensor chip surface. Analysis of the sensogram data indicated that the equilibrium association constant $\left(\mathrm{K}_{\mathrm{A}}\right)$ values were in the nanomolar range, which reflects an overall high affinity of the RBPs for host cells. Such binding affinity at the nanomolar level is in agreement with previous findings of Marti et al. (2013) [95], who investigated the interaction between the RBP of Salmonella phage S16 and wild-type Salmonella cells. Experiments showed that SPR signals were obtained after exposure of RBP Gp17 saturated gold sensor to different concentrations $\left(10^{6}, 10^{5}, 10^{4}, 10^{3}, 10^{2} \mathrm{cfu} / \mathrm{mL}\right)$ of $Y$. enterocolitica O:3. The lowest signal for bacterial capture was achieved at a cell concentration of $10^{3} \mathrm{cfu} / \mathrm{mL}$, compared to control samples that were not recognized. Similarly, a genetically engineered tail spike protein derived from Salmonella phage P22, anchored to a gold surface via an N-terminal cysteine tag, was able to detect Salmonella cells through SPR at a concentration of $10^{3} \mathrm{cfu} / \mathrm{mL}$ [96]. Likewise, an RBP from Campylobacter phage NCTC 12673 fused to glutathione S transferase (GST), and attached to an SPR surface using self-assembled glutathione monolayers, achieved a similarly low detection limit of $10^{2} \mathrm{cfu} / \mathrm{mL}$ [97]. These observations suggest the produced RBPs retain their biological function and represent highly specific reagents with an affinity for the predominant $Y$. enterocolitica serotypes implicated in yersinosis, and can be applied for use in diagnostics. 


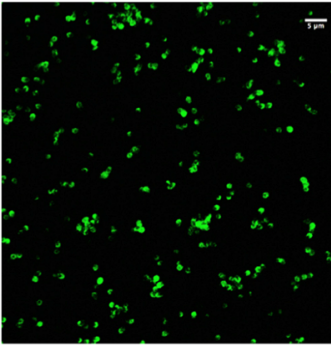

a

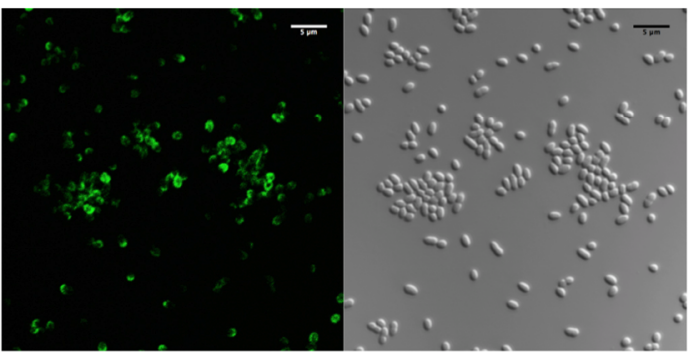

e

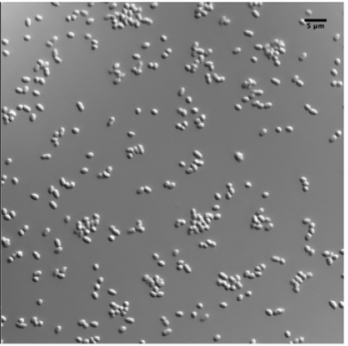

b

f

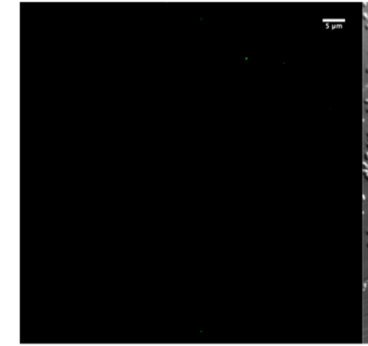

C

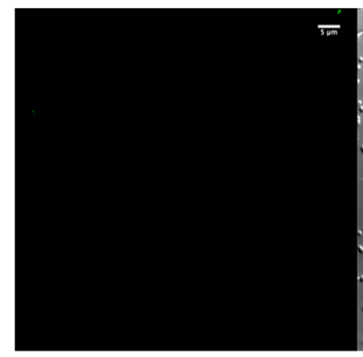

$\mathbf{g}$

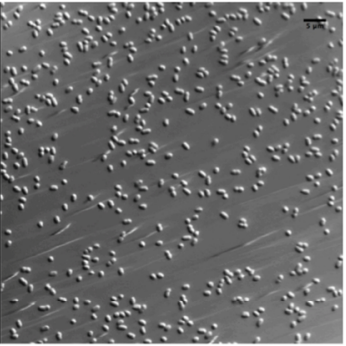

d

Figure 1. Confocal immunofluorescence microscopy images of $Y$. enterocolitica cells after incubation with Receptor Binding Proteins (RBPs) derived from phages vB_YenP_AP5 and $\varphi 80-18$. Bacterial cells were exposed to $\mathrm{N}$-terminal $\mathrm{His}_{6}$-tagged RBPs followed by immunolabelling with anti-His 6 mouse monoclonal antibody and goat anti-mouse DyLight 488 conjugated secondary antibody. RBP Gp17 derived from phage $\mathrm{vB}$ _YenP_AP5 decorates the cell surface of a Y. enterocolitica strain YeO3 of serotype O:3 (a), while deletion of the phage receptor (O-PS) in the Y. enterocolitica strain YeO3-R2 abolishes cell decoration by RBP Gp17 (c). Similarly, in (e), RBP Gp47 derived from phage $\varphi 80-18$ decorates the cell surface of the Y. enterocolitica strain 8081 of serotype O:8, whereas, the deletion of the phage receptor (O-PS) in the Y. enterocolitica strain 8081-R2 abolishes cell decoration by RBP Gp47

(g). Differential interference contrast microscopy of images of a, c, e, and g, are shown in b, d, f, and h, respectively. Scale bars represent the size in $\mu \mathrm{m}$ [31].

\subsection{Agglutination Assays}

An immediate application of RBPs is as an alternative to antibodies for the rapid screening of suspect colonies from culture isolation plates. RBPs are multimeric structures like antibodies; therefore, they are expected also to cross-link and agglutinate target bacterial cells [98,99]. To explore the agglutinating capability of Gp17, slide agglutination reactions were performed using individual Y. enterocolitica O:3 colonies obtained from growth on different agars used for routine isolation of this organism from contaminated foods, including MacConkey agar, Cefsulodin-irgasan-novobiocin (CIN) agar, Salmonella-Shigella agar supplemented with Sodium Desoxycholate and Calcium Chloride (SSDC), and CHROMagar Yersinia agar (CAY). Agglutination was observed within 5 min and was not affected by growth on these selective agars, whereas no agglutination reactions were observed with YeO3-R2 (an O-PS-deficient LPS mutant which lacks the phage receptor). The minimum agglutination concentration of RBP Gp17 resulting in cell agglutination was estimated at approximately $130 \mathrm{ng} / \mathrm{mL}$ and showed equivalent agglutination to that of $Y$. enterocolitica $\mathrm{O}: 3$ antisera [31].

\subsection{Use of RBPs for the Selective Isolation of Y. enterocolitica from Foods}

Present culture methods are considered inadequate and insufficiently sensitive to detect low levels of pathogenic Y. enterocolitica in foods, water, and environmental samples because they suffer 
from lengthy incubation times, cultural bias, and lack specificity $[8,100,101]$. As a result, numerous culture-independent methods have been devised for the rapid detection of $Y$. enterocolitica including: ELISA [102], lateral flow immunoassays [103], immunoblotting [104], DNA colony hybridization [105], PCR [106,107], nested PCR [108], real-time PCR [109], DNA microarrays [110], and loop-mediated isothermal amplification (LAMP) [111]. Among these, molecular-based methods have served to investigate the occurrence of pathogenic $Y$. enterocolitica in foods. Studies have shown the prevalence of naturally contaminated foods is significantly higher when estimated by PCR than by culture methods from epidemiologically relevant foods, highlighting the low sensitivity of culture methods $[100,112,113]$. Difficulties in isolation are largely due to low numbers of the organism present against a large number of background microbiota, and slower growth than other competing Gram-negative bacteria [8,114-118]. Specifically, different strains vary in tolerance to selective agents and incubation conditions during isolation $[105,113,119,120]$. Numerous approaches have been established utilizing combinations of cold pre-enrichment, potassium hydroxide $(\mathrm{KOH})$ treatment, selective enrichments, and the use of varied selective and differential agars for isolation $[8,100]$. Taking into account all these challenges, alternative approaches for the cultural isolation of this organism from foods are required.

A promising approach is through selective capture via the use of immunomagnetic separation (IMS) [121]. Although IMS has been investigated previously as an aid for the isolation of pathogenic Y. enterocolitica from foods [122-127], the approach did not find acceptance for routine isolation. It is perhaps because immunological-based methods require antibodies produced by laboratory animals, which suffer from lot to lot heterogeneity and instability against environmental factors [128]. Furthermore, antisera to only a limited number of $Y$. enterocolitica serotypes are commercially available. Although the production of monoclonal antibodies (mAbs) with potentially higher specificity against Y. enterocolitica has also been explored, the similar bacterial surface structures within the genus make the selection of mAbs with high specificity against a particular serotype rather difficult and costly $[104,129,130]$. We sought then to investigate the use of magnetic microparticles functionalized with the phage RBPs Gp17, Gp47, or Gp37 as an alternative to antibodies for the isolation of Y. enterocolitica from foods. The aim was to utilize a phage RBP-based magnetic separation (RBP-MS) approach for the specific and simultaneous capture of the epidemiologically significant $Y$. enterocolitica serotypes O:3, O:5,27, O:8, and or O:9.

Selective capture of Y. enterocolitica of serotype O:3, the most significant serotype causing yersiniosis, was achieved from cell suspensions by use of magnetic microparticles coated with the RBP Gp17 derived from phage $\mathrm{vB}_{-} Y e n P \_A P 5$. However, the simultaneous capture of $Y$. enterocolitica $\mathrm{O}: 3, \mathrm{O}: 5,27$, O:8 or O:9, the predominant serotypes involved in yersiniosis, was attained utilizing a mixture of magnetic microparticles coated with RBPs Gp47 and Gp37 derived from phages $\varphi 80-18$ and phage vB_YenM_TG1, respectively [31]. When applied to cell suspensions of 160 Yersinia strains and 20 other non-Yersinia spp. in combination with CIN agar, the strains isolated reflected the combined binding spectrum of the RBPs. Overall, the specificity obtained for the isolation of Y. enterocolitica O:3, O:5,27, $\mathrm{O}: 8$, and O:9 in combination with CIN agar was estimated at $85 \%$. In contrast, the application of a mixture of RBP Gp47 and Gp37 coated microparticles in combination with CAY agar, a chromogenic medium selective for virulent $Y$. enterocolitica, increased the specificity to $95.7 \%$. Pathogenic strains of serotype O:3, O:5,27, O:8 and O:9 were captured and grew as typical mauve colored colonies on this agar, whereas non-pathogenic strains grew as metallic blue or white translucent colonies including avirulent serotype O:7,8 strains that are rather common among biotype $1 A$ strains [131] and O:6,30, O:6,31, which are isolated most often [132]. Only the rarely encountered pathogenic O:1 and O:2 strains, O:5, and O:6 strains, showed similar morphological characteristics to that of pathogenic O:3 strains on CAY agar [31]. More importantly, this approach prevented the appearance of confounding colonies that were observed with the use of CAY alone from the growth of some Y. aleksiciae, Y. bercovieri, Y. kristensenii, Y. mollareti, and Y. rohdei strains, as well as Aeromonas hydrophila and Stenotrophomonas maltophilia [31]. This is of significance since $Y$. frederiksenii and $Y$. bercovieri are considered the most commonly encountered species obtained during the routine culture isolation of Y. enterocolitica [133], and pose a challenge to 
the routine application of chromogenic agars since they appear indistinguishable from pathogenic Y. enterocolitica [134-136].

Lastly, when RBP-MS was applied to artificially inoculated ground pork samples homogenized in PBS, it established a 2- $\log _{10} \mathrm{cfu} / \mathrm{g}$ improvement in sensitivity compared to direct plating on CIN or CAY agars alone [31]. In addition, RBP-MS, in combination with CAY agar, was able to detect a higher number of $Y$. enterocolitica in ground pork, mixed salad, and milk samples inoculated at low levels $(0.1 \mathrm{cfu} / \mathrm{g}, 1 \mathrm{cfu} / \mathrm{g}$, and $10 \mathrm{cfu} / \mathrm{g})$ after $8 \mathrm{~h}$ and $24 \mathrm{~h}$ enrichment at $25^{\circ} \mathrm{C}$ in non-selective TSB. Particularly, a marked decrease in background microbiota on the isolation plates was observed as compared to those from samples that did not undergo RBP-MS (Figure 2).

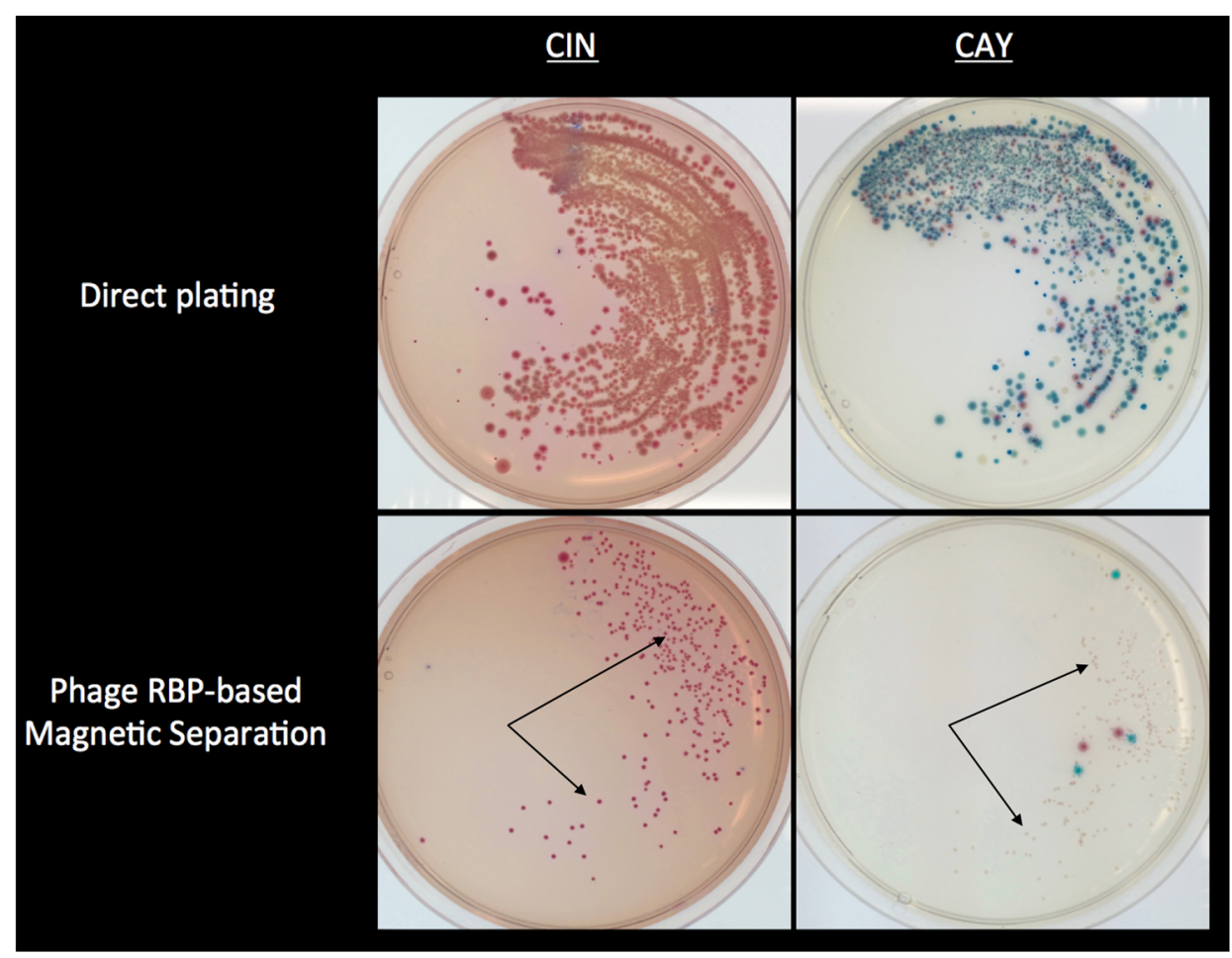

Figure 2. Effect of phage RBP-based magnetic separation in combination with CIN and CAY agar. A mixed cell suspension containing Y. enterocolitica $\mathrm{O}: 3$ cells $\left(10^{4} \mathrm{CFU} / \mathrm{mL}\right)$ at a 1:9 ratio to other competing strains (each at $10^{4} \mathrm{CFU} / \mathrm{mL}$ ) was reacted with RBP Gp17-coated magnetic microparticles and plated on Cefsulodin-irgasan-novobiocin (CIN) and CHROMagar Yersinia (CAY) agars. After incubation for $24 \mathrm{~h}$ at $30^{\circ} \mathrm{C}$ and based on the colony morphology of these agars (arrows indicate Y. enterocolitica colonies), few competing organisms could be found compared to the growth observed with the use of direct plating alone (top) [31].

In summary, RBP-based magnetic separation permits the separation of the target bacteria from competing microorganisms present in a food matrix. Unlike antibodies, however, RBPs due to their structural characteristics also offer distinct advantages such as stability to extreme $\mathrm{pH}$ values and temperature [89]. The use of phage RBPs as capture ligands represent an alternative approach for bacterial concentration that could also be used to improve the analytical sensitivity of rapid methods of analysis such as PCR or ELISA, as well as for the use in emerging biosensor based technologies. In addition, unlike intact phages, the use of RBPs provides a novel family of diagnostics that can be engineered and produced in vitro using recombinant DNA technologies, without the involvement of the phage-pathogen propagation system and the risk of cell lysis or gene transduction [89-97]. 


\section{Perspectives}

\subsection{Diversity of Yersinia Enterocolitica Phages}

The overview of the phages presented herein highlights the limited number of $Y$. enterocolitica phages for use in food safety applications. For example, among the phages examined, there is only one serotype O:8 specific phage ( $\varphi 80-18)$ reported and no serotype O:9 specific phages. Comparatively, Salem et al. [29] reported the isolation of a high frequency of O:3 specific phages and the absence of Y. enterocolitica O:9 specific phages among 95 Y. enterocolitica phages isolated from 793 pig stool samples taken at 14 Finnish farms [29]. These observations support the need to isolate and characterize novel Y. enterocolitica bacteriophages in order to expand the repertoire of candidate phages for use in food safety applications. So far, however, few potential sources for phages have been considered, such as raw sewage, farm manure (pig manure), and soil. Moreover, given that the sampling of environmental phages seems to be influenced by the methodology employed [137]; there exists a large diversity of potentially useful phages left unexplored limited by the present isolation and propagation approaches.

\subsection{Synthesis of RBPS}

It is important also to highlight that the assembly pathways of RBPs may complicate their synthesis as functional ligands for use in diagnostics. For some RBPs, phage-encoded chaperone proteins participate in the assembly and disaggregation of supramolecular structures and are required for the correct folding and assembly of RBPs into homotrimers, which is essential for functional activity [138-143]. Notably, the mechanisms for protein folding were different for each of the three RBPs produced. RBPs Gp17 and Gp47 folded endogenously when expressed in E. coli, as has been reported for other Podoviruses $[108,144]$. However, the RBP protein sequence of phage vB_YenP_AP5 was found to contain an intramolecular chaperone (ICD) which mediates quaternary folding and auto-proteolysis, excising itself from the stable, mature trimer $[103,145,146]$. This mechanism was first described in phage proteins belonging to different but structurally similar protein families: bacteriophage endosialidases, capsule depolymerases, and appendage proteins [103,147-150]. This ICD domain is also present in other Y. enterocolitica infecting phages ( $\varphi$ YeO3-12, vB_YenP_AP10, phiYe-F10, $\varphi$ R2-01), and thus, the synthesis of their respective RBP proteins is also readily attainable. In contrast, the long tail fiber protein Gp37 derived from the myovirus vB_YenM_TG1 was produced via simultaneous co-expression with the bacteriophage encoded chaperones Gp38 and Gp57A in a two-vector system as described for the expression of the long-tail fiber protein of phage T4 [151].

Several other protein-engineering strategies have also been proposed to circumvent the need for co-expression with chaperone proteins to guide the production of existing and as of yet unidentified potential RBP ligands that may be considered for use in detection assays. These approaches involve the use of foldons, carrier partners that promote proper folding, increase solubility, and enhance expression [152,153]. Among these, the T4 fibritin trimerization domain (aa 1-31) [154-156], the phage T4 trimerization motif of the structural protein Gp5 (aa 435-575) [157-160], and E. coli SLyD (aa 1-165) which performs chaperone functions [161,162], merit consideration.

\subsection{Acceptance of Phages for Biocontrol}

Although several phage-based products have been commercially available in the food industry since the regulatory acceptance of the first phage-based product in 2006, regulatory issues related to the application of phages in foods are still considered a major obstacle [4]. Regulatory authorities usually follow the existing regulations approved for ordinary drugs as there have been no guidelines established for regulatory approval of phages. Until now, there is no scientific evidence that phages themselves could impose a safety problem. In spite of this, regulatory authorities still consider phages as a potential risk. However, it is not necessary to maintain a negative perception of phages just because phages do not meet existing guidelines designed for drugs such as antibiotics. Therefore, a regulatory framework that is suitable for phages should be developed as soon as possible $[4,163]$. There is no 
doubt that further extensive research is required for the widespread use of phages. It is essential to establish adequate phage preparation methodologies as phage characterization, and purification are closely related to safety $[164,165]$. We are looking forward to the beginning of a new era of phages.

Funding: This research received no external funding.

Conflicts of Interest: The authors declare no conflict of interest. Open access funding was provided by the University of Helsinki.

\section{References}

1. Hendrix, R.W. Bacteriophages: Evolution of the majority. Theor. Popul. Biol. 2002, 61, 471-480. [CrossRef] [PubMed]

2. Bergh, O.; Borsheim, K.Y.; Bratbak, G.; Heldal, M. High abundance of viruses found in aquatic environments. Nature 1989, 340, 467-468. [CrossRef] [PubMed]

3. Casjens, S. The diverse and dynamic structure of bacterial genomes. Annu. Rev. Genet. 1998, 32, 339-377. [CrossRef] [PubMed]

4. Maura, D.; Debarbieux, L. Bacteriophages as twenty-first century antibacterial tools for food and medicine. Appl. Microbiol. Biotechnol. 2011, 90, 851-859. [CrossRef] [PubMed]

5. Jun, J.W.; Kim, H.J.; Yun, S.K.; Chai, J.Y.; Park, S.C. Eating oysters without risk of vibriosis: Application of a bacteriophage against Vibrio parahaemolyticus in oysters. Int. J. Food Microbiol. 2014, 188, 31-35. [CrossRef] [PubMed]

6. Centers for Disease Control and Prevention. Yersinia enterocolitica (Yersiniosis). 2016. Available online: https://www.cdc.gov/yersinia/ (accessed on 23 May 2019).

7. McNally, A.; Thomson, N.R.; Reuter, S.; Wren, B.W. 'Add, stir and reduce': Yersinia spp. as model bacteria for pathogen evolution. Nat. Rev. Microbiol. 2016, 14, 177-190. [CrossRef] [PubMed]

8. Bottone, E.J. Yersinia enterocolitica: Overview and epidemiologic correlates. Microbes Infect. 1999, 1, 323-333. [CrossRef]

9. EFSA; ECDC. The European Union summary report on trends and sources of zoonoses, zoonotic agents and food-borne outbreaks in 2013. EFSA J. 2015, 13, 3991. [CrossRef]

10. Jalava, K.; Hallanvuo, S.; Nakari, U.M.; Ruutu, P.; Kela, E.; Heinäsmäki, T.; Siitonen, A.; Nuorti, J.P. Multiple outbreaks of Yersinia pseudotuberculosis infections in Finland. J. Clin. Microbiol. 2004, 42, 2789-2791. [CrossRef]

11. Baker, P.M.; Farmer, J.J.I. New bacteriophage typing system for Yersinia enterocolitica, Yersinia kristensenii, Yersinia frederiksenii, and Yersinia intermedia: Correlation with serotyping, biotyping, and antibiotic susceptibility. J. Clin. Microbiol. 1982, 15, 491-502.

12. Bergan, T.; Norris, J.R. Bacteriophage typing of Yersinia enterocolitica. Methods Microbiol. 1978, 1, 225-236.

13. Calvo, C.; Brault, J.; Alonso, J.M.; Mollaret, H.H. New waterborne bacteriophages active on Yersinia enterocolitica. Appl. Environ. Microbiol. 1981, 42, 35-38. [PubMed]

14. Calvo, C.; Fernandez, A.; Bejar, V.; Cormenzana, A.R. Differenciation rapide des serovars O:3 et O:9 de Yersinia enterocolitica par certains bacteriophages. Ann. Inst. Pasteur/Microbiol. 1987, 138, 617-623. [CrossRef]

15. Caprioli, T.; Drapeau, A.J.; Kasatiya, S. Yersinia enterocolitica: Serotypes and biotypes isolated from humans and the environment in Quebec, Canada. J. Clin. Microbiol. 1978, 8, 7-11. [PubMed]

16. Kawaoka, Y.; Mitani, T.; Otsuki, K.; Tsubokura, M. Isolation and use of eight phages for typing Yersinia enterocolitica O3. J. Med. Microbiol. 1987, 23, 349-352. [CrossRef]

17. Kawaoka, Y.; Otsuki, K.; Tsubokura, M. Characteristics of Yersinia enterocolitica bacteriophages. Zent. Bakteriol. Mikrobiol. Hyg. 1 Abt Orig. A 1982, 253, 102-109. [CrossRef]

18. Nicolle, P.; Mollaret, H.; Hamon, Y.; Vieu, J.F. Étude lysogénique, bactériocinogénique et lysotypique de l'espèce Yersinia enterocolitica. Ann. L'Inst. Pasteur 1967, 112, 86-92.

19. Nicolle, P.; Mollaret, H.; Brault, J. Current state of research on lysogeny and lysotyping of Yersinia enterocolitica. Arch. Roum. Pathol. Exp. Microbiol. 1969, 28, 1019-1027.

20. Niléhn, B. Studies on Yersinia enterocolitica with special reference to bacterail diagnosis and occurrence in human acute enteric disease. Acta Pathol. Microbiol. Scand. 1969, 206, 1-48. 
21. Nilehn, B. Some aspects on phage typing of Yersinia enterocolitica. Acta Pathol. Microbiol. Scand. B Microbiol. Immunol. 1971, 79, 446-447.

22. Tsubokura, M.; Otsuki, K.; Kawaoka, Y.; Fukushima, H. Lysogenicity and phage typing of Yersinia enterocolitica isolated in Japan. Jpn. J. Vet. Sci. 1982, 44, 433-437. [CrossRef] [PubMed]

23. Darsavelidze, M.A.; Kapanadze Zh, S.; Chanishvili, T.G. Biological properties of bacteriophages, active to Yersinia enterocolitica. Zh. Mikrobiol. Epidemiol. I Immunobiol. 2004, 6, 10-13.

24. Hertwig, S.; Popp, A.; Freytag, B.; Lurz, R.; Appel, B. Generalized transduction of small Yersinia enterocolitica plasmids. Appl. Environ. Microbiol. 1999, 65, 3862-3866. [PubMed]

25. Kot, B.; Bukowski, K.; Jakubczak, A.; Kaczorek, I. The activity of chosen bacteriophages on Yersinia enterocolitica strains. Pol. J. Vet. Sci. 2002, 5, 47-50. [PubMed]

26. Kudriakova, T.A.; Makedonova, L.D.; Kachkina, G.V.; Saiamov, S.R. Yersinia enterocolitica bacteriophages: Detection and identification. Klin. Lab. Diagn. 2010, 4, 43-45.

27. Popp, A.; Hertwig, S.; Lurz, R.; Appel, B. Comparative study of temperate bacteriophages isolated from Yersinia. Syst. Appl. Microbiol. 2000, 23, 469-478. [CrossRef]

28. Salem, M.; Skurnik, M. Genomic Characterization of Sixteen Yersinia enterocolitica-Infecting Podoviruses of Pig Origin. Viruses 2018, 10, 174. [CrossRef]

29. Salem, M.; Virtanen, S.; Korkeala, H.; Skurnik, M. Isolation and characterization of Yersinia-specific bacteriophages from pig stools in Finland. J. Appl. Microbiol. 2015, 118, 599-608. [CrossRef]

30. Pajunen, M.I.; Kiljunen, S.J.; Söderholm, M.-E.L.; Skurnik, M. Complete genomic sequence of the lytic bacteriophage fYeO3-12 of Yersinia enterocolitica serotype O:3. J. Bacteriol. 2001, 183, 1928-1937. [CrossRef]

31. Leon-Velarde, C.G. The Application of Bacteriophage Host Recognition Binding Proteins for the Isolation of Yersinia enterocolitica in Foods. Ph.D. Thesis, University of Guelph, Guelph, ON, Canada, 2017.

32. Leon-Velarde, C.G.; Kropinski, A.M.; Chen, S.; Abbasifar, A.; Griffiths, M.W.; Odumeru, J.A. Complete genome sequence of bacteriophage vB_YenP_AP5 which infects Yersinia enterocolitica of serotype O:3. Virol. J. 2014, 11, 188. [CrossRef]

33. Liang, J.; Li, X.; Zha, T.; Chen, Y.; Hao, H.; Liu, C.; Duan, R.; Xiao, Y.; Su, M.; Wang, X.; et al. dTDP-rhamnosyl transferase $\mathrm{RfbF}$, is a newfound receptor-related regulatory protein for phage phiYe-F10 specific for Yersinia enterocolitica serotype O:3. Sci. Rep. 2016, 6, 22905. [CrossRef] [PubMed]

34. Biedzka-Sarek, M.; Jarva, H.; Hyytiäinen, H.; Meri, S.; Skurnik, M. Characterization of complement factor H binding to Yersinia enterocolitica serotype O:3. Infect. Immun. 2008, 76, 4100-4109. [CrossRef] [PubMed]

35. Zhang, L.; Skurnik, M. Isolation of an $\mathrm{R}^{-} \mathrm{M}^{+}$mutant of Yersinia enterocolitica serotype O:8 and its application in construction of rough mutants utilizing mini-Tn5 derivatives and lipopolysaccharide-specific phage. J. Bacteriol. 1994, 176, 1756-1760. [CrossRef] [PubMed]

36. Jun, J.W.; Park, S.C.; Wicklund, A.; Skurnik, M. Bacteriophages reduce Yersinia enterocolitica contamination of food and kitchenware. Int. J. Food Microbiol. 2018, 271, 33-47. [CrossRef]

37. Pajunen, M.I.; Happonen, L.J.; Jun, J.W.; Malmström, J.; Nawaz, A.; Mattinen, L.; Skurnik, M. Genomic, functional and proteomic characterization of the T5-like bacteriophage $\phi R 2-01$ infecting Yersinia enterocolitica. J. Virol. 2019. submitted.

38. Hertwig, S.; Klein, I.; Hammerl, J.A.; Appel, B. Characterization of two conjugative Yersinia plasmids mobilizing pYV. Adv. Exp. Med. Biol. 2003, 529, 35-38.

39. Hertwig, S.; Klein, I.; Lurz, R.; Lanka, E.; Appel, B. PY54, a linear plasmid prophage of Yersinia enterocolitica with covalently closed ends. Mol. Microbiol. 2003, 48, 989-1003. [CrossRef]

40. Hertwig, S.; Klein, I.; Schmidt, V.; Beck, S.; Hammerl, J.A.; Appel, B. Sequence analysis of the genome of the temperate Yersinia enterocolitica phage PY54. J. Mol. Biol. 2003, 331, 605-622. [CrossRef]

41. Kiljunen, S.; Hakala, K.; Pinta, E.; Huttunen, S.; Pluta, P.; Gador, A.; Lönnberg, H.; Skurnik, M. Yersiniophage fR1-37 is a tailed bacteriophage having a $270 \mathrm{~kb}$ DNA genome with thymidine replaced by deoxyuridine. Microbiology 2005, 151, 4093-4102. [CrossRef]

42. Skurnik, M.; Hyytiäinen, H.J.; Happonen, L.J.; Kiljunen, S.; Datta, N.; Mattinen, L.; Williamson, K.; Kristo, P.; Szeliga, M.; Kalin-Mänttäri, L.; et al. Characterization of the genome, proteome, and structure of yersiniophage fR1-37. J. Virol. 2012, 86, 12625-12642. [CrossRef]

43. Skurnik, M.; Venho, R.; Toivanen, P.; Al-Hendy, A. A novel locus of Yersinia enterocolitica serotype O:3 involved in lipopolysaccharide outer core biosynthesis. Mol. Microbiol. 1995, 17, 575-594. [CrossRef] [PubMed] 
44. Leon-Velarde, C.G.; Happonen, L.; Pajunen, M.; Leskinen, K.; Kropinski, A.M.; Mattinen, L.; Rajtor, M.; Zur, J.; Smith, D.; Chen, S.; et al. Yersinia enterocolitica-specific infection by bacteriophages TG1 and fR1-RT is dependent on temperature-regulated expression of the phage host receptor OmpF. Appl. Environ. Microbiol. 2016, 82, 5340-5353. [CrossRef] [PubMed]

45. Hertwig, S.; Klein, I.; Appel, B. Properties of the temperate Yersinia enterocolitica bacteriophage PY54. Adv. Exp. Med. Biol. 2003, 529, 241-243. [PubMed]

46. ECDC. Surveillance of Seven Priority Food-and Waterborne Diseases in the EU/EEA; ECDC: Solna Municipality, Sweden, 2015.

47. Al-Hendy, A.; Toivanen, P.; Skurnik, M. Expression cloning of Yersinia enterocolitica O:3 rfb gene cluster in Escherichia coli K12. Microb. Pathog. 1991, 10, 47-59. [CrossRef]

48. Pajunen, M.; Kiljunen, S.; Skurnik, M. Bacteriophage fYeO3-12, specific for Yersinia enterocolitica serotype O:3, is related to coliphages T3 and T7. J. Bacteriol. 2000, 182, 5114-5120. [CrossRef]

49. Bruneteau, M.; Minka, S. Lipopolysaccharides of bacterial pathogens from the genus Yersinia: A mini-review. Biochimie 2003, 85, 145-152. [CrossRef]

50. Gorshkova, R.P.; Kalmykova, E.N.; Isakov, V.V.; Ovodov, Y.S. Structural studies on O-specific polysaccharides of lipopolysaccharides from Yersinia enterocolitica serovars O:1,2a,3, O:2a,2b,3 and O:3. Eur. J. Biochem. 1985, 150, 527-531. [CrossRef]

51. Hoffman, J.; Lindberg, B.; Brubaker, R.R. Structural studies of the O-specific side-chains of the lipopolysaccharide from Yersinia enterocolitica Ye 128. Carbohydr. Res. 1980, 78, 212-214. [CrossRef]

52. Skurnik, M. My life with Yersinia. Adv. Exp. Med. Biol. 2007, 603, 44-73.

53. Haggård-Ljungquist, E.; Halling, C.; Calendar, R. DNA sequences of the tail fiber genes of bacteriophage P2: Evidence for horizontal transfer of tail fiber genes among unrelated bacteriophages. J. Bacteriol. 1992, 174, 1462-1477. [CrossRef]

54. Werts, C.; Michel, V.; Hofnung, M.; Charbit, A. Adsorption of bacteriophage lambda on the LamB protein of Escherichia coli K-12: Point mutations in gene J of lambda responsible for extended host range. J. Bacteriol. 1994, 176, 941-947. [CrossRef] [PubMed]

55. Tam, W.; Pell, L.G.; Bona, D.; Tsai, A.; Dai, X.X.; Edwards, A.M.; Hendrix, R.W.; Maxwell, K.L.; Davidson, A.R. Tail tip proteins related to bacteriophage lambda gpL coordinate an iron-sulfur cluster. J. Mol. Biol. 2013, 425, 2450-2462. [CrossRef] [PubMed]

56. Wang, J.; Hofnung, M.; Charbit, A. The C-terminal portion of the tail fiber protein of bacteriophage lambda is responsible for binding to LamB, its receptor at the surface of Escherichia coli K-12. J. Bacteriol. 2000, 182, 508-512. [CrossRef] [PubMed]

57. Berkane, E.; Orlik, F.; Stegmeier, J.F.; Charbit, A.; Winterhalter, M.; Benz, R. Interaction of bacteriophage lambda with its cell surface receptor: An in vitro study of binding of the viral tail protein gpJ to LamB (Maltoporin). Biochemistry 2006, 45, 2708-2720. [CrossRef] [PubMed]

58. Randall-Hazelbauer, L.; Schwartz, M. Isolation of the bacteriophage lambda receptor from Escherichia coli. J. Bacteriol. 1973, 116, 1436-1446. [PubMed]

59. Effantin, G.; Boulanger, P.; Neumann, E.; Letellier, L.; Conway, J.F. Bacteriophage T5 structure reveals similarities with HK97 and T4 suggesting evolutionary relationships. J. Mol. Biol. 2006, 361, 993-1002. [CrossRef]

60. Garcia-Doval, C.; Luque, D.; Caston, J.R.; Boulanger, P.; van Raaij, M.J. Crystallization of the C-terminal domain of the bacteriophage T5 L-shaped fibre. Acta Crystallogr. Sect. F Struct. Biol. Cryst. Commun. 2013, 69, 1363-1367. [CrossRef]

61. Kaliman, A.V.; Kulshin, V.E.; Shlyapnikov, M.G.; Ksenzenko, V.N.; Kryukov, V.M. The nucleotide sequence of the bacteriophage T5 ltf gene. FEBS Lett. 1995, 366, 46-48. [CrossRef]

62. Heller, K.J.; Bryniok, D. O antigen-dependent mutant of bacteriophage T5. J. Virol. 1984, 49, $20-25$.

63. Mondigler, M.; Holz, T.; Heller, K.J. Identification of the receptor-binding regions of pb5 proteins of bacteriophages T5 and BF23. Virology 1996, 219, 19-28. [CrossRef]

64. Schwudke, D.; Ergin, A.; Michael, K.; Volkmar, S.; Appel, B.; Knabner, D.; Konietzny, A.; Strauch, E. Broad-host-range Yersinia phage PY100: Genome sequence, proteome analysis of virions, and DNA packaging strategy. J. Bacteriol. 2008, 190, 332-342. [CrossRef] [PubMed] 
65. Orquera, S.; Golz, G.; Hertwig, S.; Hammerl, J.; Sparborth, D.; Joldic, A.; Alter, T. Control of Campylobacter spp. and Yersinia enterocolitica by virulent bacteriophages. J. Mol. Genet. Med. 2012, 6, 273-278. [CrossRef] [PubMed]

66. Mesyanzhinov, V.V.; Robben, J.; Grymonprez, B.; Kostyuchenko, V.A.; Bourkaltseva, M.V.; Sykilinda, N.N.; Krylov, V.N.; Volckaert, G. The genome of bacteriophage $\mathrm{fKZ}$ of Pseudomonas aeruginosa. J. Mol. Biol. 2002, 317, 1-19. [CrossRef] [PubMed]

67. Pajunen, M.I.; Molineux, I.J.; Skurnik, M. Yersiniophages. In The Genus Yersinia: Entering the Functional Genomic Era; Skurnik, M., Granfors, K., Bengoechea, J.A., Eds.; Kluwer Academic: Dordrecht, The Netherlands; Plenum Publishers: New York, NY, USA, 2003; pp. 233-240.

68. Al-Hendy, A.; Toivanen, P.; Skurnik, M. Lipopolysaccharide O side chain of Yersinia enterocolitica O:3 is an essential virulence factor in an orally infected murine model. Infect. Immun. 1992, 60, 870-875.

69. Beczala, A.; Ovchinnikova, O.G.; Datta, N.; Mattinen, L.; Knapska, K.; Radziejewska-Lebrecht, J.; Holst, O.; Skurnik, M. Structure and genetic basis of Yersinia similis serotype O:9 O-specific polysaccharide. Innate Immun. 2015, 21, 3-16. [CrossRef]

70. Yu, S.L.; Ko, K.L.; Chen, C.S.; Chang, Y.C.; Syu, W.J. Characterization of the distal tail fiber locus and determination of the receptor for phage AR1, which specifically infects Escherichia coli O157:H7. J. Bacteriol. 2000, 182, 5962-5968. [CrossRef]

71. Qasim, M.S. Evaluation of Receptor-Binding Protein of Bacteriophage $\phi R 1-37$. Master's Thesis, University of Helsinki, Helsinki, Finland, 2018.

72. Adams, M.J.; Lefkowitz, E.J.; King, A.M.; Harrach, B.; Harrison, R.L.; Knowles, N.J.; Kropinski, A.M.; Krupovic, M.; Kuhn, J.H.; Mushegian, A.R.; et al. Ratification vote on taxonomic proposals to the International Committee on Taxonomy of Viruses (2016). Arch. Virol. 2016, 161, 2921-2949. [CrossRef]

73. Sulakvelidze, A. Safety by nature: Potential bacteriophage applications. Microbe Mag. 2011, 6, 122-126. [CrossRef]

74. Endersen, L.; O'Mahony, J.; Hill, C.; Ross, R.P.; McAuliffe, O.; Coffey, A. Phage therapy in the food industry. Annu. Rev. Food Sci. Technol. 2014, 5, 327-349. [CrossRef]

75. Hagens, S.; Loessner, M.J. Bacteriophage for biocontrol of foodborne pathogens: Calculations and considerations. Curr. Pharm. Biotechnol. 2010, 11, 58-68. [CrossRef]

76. Fernandez, L.; Gutierrez, D.; Garcia, P.; Rodriguez, A. The Perfect Bacteriophage for Therapeutic Applications-A Quick Guide. Antibiotics 2019, 8, 126. [CrossRef] [PubMed]

77. Goodridge, L.D.; Bisha, B. Phage-based biocontrol strategies to reduce foodborne pathogens in foods. Bacteriophage 2011, 1, 130-137. [CrossRef] [PubMed]

78. Sommer, J.; Trautner, C.; Witte, A.K.; Fister, S.; Schoder, D.; Rossmanith, P.; Mester, P.J. Don't Shut the Stable Door after the Phage Has Bolted-The Importance of Bacteriophage Inactivation in Food Environments. Viruses 2019, 11, 468. [CrossRef] [PubMed]

79. Kazi, M.; Annapure, U.S. Bacteriophage biocontrol of foodborne pathogens. J. Food Sci. Technol. 2016, 53, 1355-1362. [CrossRef] [PubMed]

80. Bennett, A.R.; Davids, F.G.C.; Vlahodimou, S.; Banks, J.G.; Betts, R.P. The use of bacteriophage-based systems for the separation and concentration of Salmonella. J. Appl. Microbiol. 1997, 83, 259-265. [CrossRef] [PubMed]

81. Blasco, R.; Murphy, M.J.; Sanders, M.F.; Squirrell, D.J. Specific assays for bacteria using phage mediated release of adenylate kinase. J. Appl. Microbiol. 1998, 84, 661-666. [CrossRef]

82. Favrin, S.J.; Jassim, S.A.; Griffiths, M.W. Development and optimization of a novel immunomagnetic separation-bacteriophage assay for detection of Salmonella enterica serovar Enteritidis in broth. Appl. Environ. Microbiol. 2001, 67, 217-224. [CrossRef]

83. Favrin, S.J.; Jassim, S.A.; Griffiths, M.W. Application of a novel immunomagnetic separation-bacteriophage assay for the detection of Salmonella enteritidis and Escherichia coli O157:H7 in food. Int. J. Food Microbiol. 2003, 85, 63-71. [CrossRef]

84. Galikowska, E.; Kunikowska, D.; Tokarska-Pietrzak, E.; Dziadziuszko, H.; Los, J.M.; Golec, P.; Wegrzyn, G.; Los, M. Specific detection of Salmonella enterica and Escherichia coli strains by using ELISA with bacteriophages as recognition agents. Eur. J. Clin. Microbiol. Infect. Dis. 2011, 30, 1067-1073. [CrossRef]

85. Jiang, L.; Jiang, Q.; Huang, K.; Zhang, C.; Tang, T. Rapid detection of Salmonella in food by using fluorescently labeled phage O-I. Acta Microbiol. Sin. 2009, 49, 372-377. 
86. Kuhn, J.; Suissa, M.; Wyse, J.; Cohen, I.; Weiser, I.; Reznick, S.; Lubinsky-Mink, S.; Stewart, G.; Ulitzur, S. Detection of bacteria using foreign DNA: The development of a bacteriophage reagent for Salmonella. Int. J. Food Microbiol. 2002, 74, 229-238. [CrossRef]

87. Minikh, O.; Tolba, M.; Brovko, L.Y.; Griffiths, M.W. Bacteriophage-based biosorbents coupled with bioluminescent ATP assay for rapid concentration and detection of Escherichia coli. J. Microbiol. Methods 2010, 82, 177-183. [CrossRef] [PubMed]

88. Thouand, G.; Vachon, P.; Liu, S.; Dayre, M.; Griffiths, M.W. Optimization and validation of a simple method using P22: LuxAB bacteriophage for rapid detection of Salmonella enterica serotypes A, B, and D in poultry samples. J. Food Prot. 2008, 71, 380-385. [CrossRef] [PubMed]

89. Tolba, M.; Minikh, O.; Brovko, L.Y.; Evoy, S.; Griffiths, M.W. Oriented immobilization of bacteriophages for biosensor applications. Appl. Environ. Microbiol. 2010, 76, 528-535. [CrossRef] [PubMed]

90. Wolber, P.K.; Green, R.L. Detection of bacteria by transduction of ice nucleation genes. Trends Biotechnol. 1990, 8, 276-279. [CrossRef]

91. Wu, Y.; Brovko, L.; Griffiths, M.W. Influence of phage population on the phage-mediated bioluminescent adenylate kinase (AK) assay for detection of bacteria. Lett. Appl. Microbiol. 2001, 33, 311-315. [CrossRef]

92. Korndorfer, I.P.; Danzer, J.; Schmelcher, M.; Zimmer, M.; Skerra, A.; Loessner, M.J. The crystal structure of the bacteriophage PSA endolysin reveals a unique fold responsible for specific recognition of Listeria cell walls. J. Mol. Biol. 2006, 364, 678-689. [CrossRef]

93. Kretzer, J.W.; Lehmann, R.; Schmelcher, M.; Banz, M.; Kim, K.P.; Korn, C.; Loessner, M.J. Use of high-affinity cell wall-binding domains of bacteriophage endolysins for immobilization and separation of bacterial cells. Appl. Environ. Microbiol. 2007, 73, 1992-2000. [CrossRef]

94. Loessner, M.J.; Kramer, K.; Ebel, F.; Scherer, S. C-terminal domains of Listeria monocytogenes bacteriophage murein hydrolases determine specific recognition and high-affinity binding to bacterial cell wall carbohydrates. Mol. Microbiol. 2002, 44, 335-349. [CrossRef]

95. Marti, R.; Zurfluh, K.; Hagens, S.; Pianezzi, J.; Klumpp, J.; Loessner, M.J. Long tail fibres of the novel broad-host-range T-even bacteriophage S16 specifically recognize Salmonella OmpC. Mol. Microbiol. 2013, 87, 818-834. [CrossRef]

96. Singh, A.; Arya, S.K.; Glass, N.; Hanifi-Moghaddam, P.; Naidoo, R.; Szymanski, C.M.; Tanha, J.; Evoy, S. Bacteriophage tailspike proteins as molecular probes for sensitive and selective bacterial detection. Biosens. Bioelectron. 2010, 26, 131-138. [CrossRef] [PubMed]

97. Singh, A.; Arutyunov, D.; McDermott, M.T.; Szymanski, C.M.; Evoy, S. Specific detection of Campylobacter jejuni using the bacteriophage NCTC 12673 receptor binding protein as a probe. Analyst 2011, 136, 4780-4786. [CrossRef] [PubMed]

98. Waseh, S.; Hanifi-Moghaddam, P.; Coleman, R.; Masotti, M.; Ryan, S.; Foss, M.; MacKenzie, R.; Henry, M.; Szymanski, C.M.; Tanha, J. Orally administered P22 phage tailspike protein reduces Salmonella colonization in chickens: Prospects of a novel therapy against bacterial infections. PLoS ONE 2010, 5, e13904. [CrossRef] [PubMed]

99. Kropinski, A.M.; Arutyunov, D.; Foss, M.; Cunningham, A.; Ding, W.; Singh, A.; Pavlov, A.R.; Henry, M.; Evoy, S.; Kelly, J.; et al. Genome and proteome of Campylobacter jejuni bacteriophage NCTC 12673. Appl. Environ. Microbiol. 2011, 77, 8265-8271. [CrossRef] [PubMed]

100. Fredriksson-Ahomaa, M.; Korkeala, H. Low occurrence of pathogenic Yersinia enterocolitica in clinical, food, and environmental samples: A methodological problem. Clin. Microbiol. Rev. 2003, 16, 220-229. [CrossRef] [PubMed]

101. Cocolin, L.; Comi, G. Use of a culture-independent molecular method to study the ecology of Yersinia spp. in food. Int. J. Food Microbiol. 2005, 105, 71-82. [CrossRef]

102. Balakrishna, K.; Murali, H.S.; Batra, H.V. Cloning, expression and characterization of attachment-invasion locus protein (Ail) of Yersinia enterocolitica and its utilization in rapid detection by immunoassays. Lett. Appl. Microbiol. 2010, 50, 131-137. [CrossRef]

103. Schwarzer, D.; Stummeyer, K.; Gerardy-Schahn, R.; Muhlenhoff, M. Characterization of a novel intramolecular chaperone domain conserved in endosialidases and other bacteriophage tail spike and fiber proteins. J. Biol. Chem. 2007, 282, 2821-2831. [CrossRef] 
104. Khamjing, W.; Khongchareonporn, N.; Rengpipat, S. Detection by using monoclonal antibodies of Yersinia enterocolitica in artificially-contaminated pork. Microbiol. Immunol. 2011, 55, 605-615. [CrossRef]

105. Nesbakken, T.; Kapperud, G.; Dommarsnes, K.; Skurnik, M.; Hornes, E. Comparative study of a DNA hybridization method and two isolation procedures for detection of Yersinia enterocolitica O:3 in naturally contaminated pork products. Appl. Environ. Microbiol. 1991, 57, 389-394.

106. Kaneko, S.; Ishizaki, N.; Kokubo, Y. Detection of pathogenic Yersinia enterocolitica and Yersinia pseudotuberculosis from pork using the polymerase chain reaction. In Yersiniosis: Present and Future; Ravagnan, G., Chiesa, C., Eds.; Karger: Basel, Switzerland, 1995; pp. 153-155.

107. Lantz, P.G.; Knutsson, R.; Blixt, Y.; Al Soud, W.A.; Borch, E.; Rådström, P. Detection of pathogenic Yersinia enterocolitica in enrichment media and pork by a multiplex PCR: A study of sample preparation and PCR-inhibitory components. Int. J. Food Microbiol. 1998, 45, 93-105. [CrossRef]

108. Garcia-Doval, C.; van Raaij, M.J. Structure of the receptor-binding carboxy-terminal domain of bacteriophage T7 tail fibers. Proc. Natl. Acad. Sci. USA 2012, 109, 9390-9395. [CrossRef] [PubMed]

109. Lambertz, S.T.; Nilsson, C.; Hallanvuo, S.; Lindblad, M. Real-time PCR method for detection of pathogenic Yersinia enterocolitica in food. Appl. Environ. Microbiol. 2008, 74, 6060-6067. [CrossRef] [PubMed]

110. Bang, J.; Beuchat, L.R.; Gu, M.B.; Chang, H.I.; Ryu, J.H. Identification of Yersinia enterocolitica using a random genomic DNA microarray chip. Lett. Appl. Microbiol. 2010, 51, 665-670. [CrossRef] [PubMed]

111. Gao, H.; Lei, Z.; Jia, J.; Wang, S.; Chen, Y.; Sun, M.; Liang, C. Application of loop-mediated isothermal amplification for detection of Yersinia enterocolitica in pork meat. J. Microbiol. Methods 2009, 77, 198-201. [CrossRef] [PubMed]

112. Boyapalle, S.; Wesley, I.V.; Hurd, H.S.; Reddy, P.G. Comparison of culture, multiplex, and 5' nuclease polymerase chain reaction assays for the rapid detection of Yersinia enterocolitica in swine and pork products. J. Food Prot. 2001, 64, 1352-1361. [CrossRef] [PubMed]

113. Johannessen, G.S.; Kapperud, G.; Kruse, H. Occurrence of pathogenic Yersinia enterocolitica in Norwegian pork products determined by a PCR method and a traditional culturing method. Int. J. Food Microbiol. 2000, 54, 75-80. [CrossRef]

114. Arnold, T.; Neubauer, H.; Nikolaou, K.; Roesler, U.; Hensel, A. Identification of Yersinia enterocolitica in minced meat: A comparative analysis of API 20E, Yersinia identification kit and a $16 \mathrm{~S}$ rRNA-based PCR method. J. Vet. Med. B Infect. Dis. Vet. Public Health 2004, 51, 23-27. [CrossRef]

115. De Boer, E. Isolation of Yersinia enterocolitica from foods. Int. J. Food Microbiol. 1992, 17, 75-84. [CrossRef]

116. Schiemann, D.A.; Olson, S.A. Antagonism by gram-negative bacteria to growth of Yersinia enterocolitica in mixed cultures. Appl. Environm. Microbiol. 1984, 48, 539-544.

117. Schiemann, D.A. Synthesis of a selective agar medium for Yersinia enterocolitica. Can. J. Microbiol. 1979, 25, 1298-1304. [CrossRef] [PubMed]

118. Fukushima, H. New selective agar medium for isolation of virulent Yersinia enterocolitica. J. Clin. Microbiol. 1987, 25, 1068-1073. [PubMed]

119. Kwaga, J.; Iversen, J.O. In Vitro Antimicrobial Susceptibles of Yersinia enterocolitica and Related Species Isolated from Slaughtered Pigs and Pork Products. Antimicrob. Agents Chemother. 1990, 34, 2423-2425. [CrossRef] [PubMed]

120. Wauters, G.; Goossens, V.; Janssens, M.; Vandepitte, J. New enrichment method for isolation of pathogenic Yersinia enterocolitica serogroup O:3 from pork. Appl. Environm. Microbiol. 1988, 54, 851-854.

121. Stevens, K.A.; Jaykus, L.A. Bacterial separation and concentration from complex sample matrices: A review. Crit. Rev. Microbiol. 2004, 30, 7-24. [CrossRef]

122. Ueda, S. Simultaneous detection of some Yersinia enterocolitica serovars from food and human samples by PCR after IMS-plating. Biocontrol Sci. 2005, 10, 111-115. [CrossRef]

123. Ueda, S.; Maruyama, T.; Kuwabara, A. A method combined immunomagnetic separation followed by plating and polymerase chain reaction assay for the detection of pathogenic Yersinia enterocolitica from food and fecal samples. Biocontrol Sci. 2003, 8, 77-86. [CrossRef]

124. Rasmussen, H.N.; Rasmussen, O.F.; Christensen, H.; Olsen, J.E. Detection of Yersinia enterocolitica O:3 in faecal samples and tonsil swabs from pigs using IMS and PCR. J. Appl. Bact. 1995, 78, 563-568. [CrossRef] 
125. Kapperud, G.; Vardund, T.; Skjerve, E.; Hornes, E.; Michaelsen, T.E. Detection of pathogenic Yersinia enterocolitica in foods and water by immunomagnetic separation, nested polymerase chain reactions, and colorimetric detection of amplified DNA. Appl. Environ. Microbiol. 1993, 59, 2938-2944.

126. Estrada, C.S.; Velazquez Ldel, C.; Favier, G.I.; Genaro, M.S.; Escudero, M.E. Detection of Yersinia spp. in meat products by enrichment culture, immunomagnetic separation and nested PCR. Food Microbiol. 2012, 30, 157-163. [CrossRef]

127. Koujitani, E.; Horisaka, T.; Nomura, Y.; Hara-Kudo, Y.; Okatani, A.T.; Iwata, T.; Kumagai, S.; Hayashidani, H. Immuno-magnetic separation and agar layer methods for the isolation of freeze-injured Yersinia enterocolitica O:8 from water. J. Vet. Med. Sci. 2006, 68, 195-199. [CrossRef] [PubMed]

128. Wang, W.; Singh, S.; Zeng, D.L.; King, K.; Nema, S. Antibody structure, instability, and formulation. J. Pharm. Sci. 2007, 96, 1-26. [CrossRef] [PubMed]

129. Laporte, J.; Savin, C.; Lamourette, P.; Devilliers, K.; Volland, H.; Carniel, E.; Creminon, C.; Simon, S. Fast and sensitive detection of enteropathogenic Yersinia by immunoassays. J. Clin. Microbiol. 2015, 53, 146-159. [CrossRef] [PubMed]

130. Kooi, C.; Sokol, P.A. Characterization of monoclonal antibodies to Yersinia enterocolitica iron-regulated proteins. Can. J. Microb. 1995, 41, 562-571. [CrossRef] [PubMed]

131. Sihvonen, L.M.; Jalkanen, K.; Huovinen, E.; Toivonen, S.; Corander, J.; Kuusi, M.; Skurnik, M.; Siitonen, A.; Haukka, K. Clinical isolates of Yersinia enterocolitica Biotype 1A represent two phylogenetic lineages with differing pathogenicity-related properties. BMC Microbiol. 2012, 12, 208. [CrossRef] [PubMed]

132. Tennant, S.M.; Grant, T.H.; Robins-Browne, R.M. Pathogenicity of Yersinia enterocolitica biotype 1A. FEMS Immunol. Med. Microbiol. 2003, 38, 127-137. [CrossRef]

133. Sihvonen, L.M.; Haukka, K.; Kuusi, M.; Virtanen, M.J.; Siitonen, A.; YE Study Group. Yersinia enterocolitica and Y. enterocolitica-like species in clinical stool specimens of humans: Identification and prevalence of bio/serotypes in Finland. Eur. J. Clin. Microbiol. Infect. Dis. 2009, 28, 757-765. [CrossRef]

134. Denis, M.; Houard, E.; Labbe, A.; Fondrevez, M.; Salvat, G. A Selective Chromogenic Plate, YECA, for the Detection of Pathogenic Yersinia enterocolitica: Specificity, Sensitivity, and Capacity to Detect Pathogenic $Y$. enterocolitica from Pig Tonsils. J. Pathog. 2011, 2011, 296275. [CrossRef]

135. Karhukorpi, J.; Päivänurmi, M. Differentiation of Yersinia enterocolitica biotype 1A from pathogenic Yersinia enterocolitica biotypes by detection of beta-glucosidase activity: Comparison of two chromogenic culture media and Vitek2. J. Med. Microbiol. 2014, 63, 34-37. [CrossRef]

136. Renaud, N.; Lecci, L.; Courcol, R.J.; Simonet, M.; Gaillot, O. CHROMagar Yersinia, a new chromogenic agar for screening of potentially pathogenic Yersinia enterocolitica isolates in stools. J. Clin. Microbiol. 2013, 51, 1184-1187. [CrossRef]

137. Serwer, P.; Hayes, S.J.; Thomas, J.A.; Hardies, S.C. Propagating the missing bacteriophages: A large bacteriophage in a new class. Virol. J. 2007, 4, 21. [CrossRef] [PubMed]

138. Bartual, S.G.; Garcia-Doval, C.; Alonso, J.; Schoehn, G.; van Raaij, M.J. Two-chaperone assisted soluble expression and purification of the bacteriophage T4 long tail fibre protein gp37. Protein Expr. Purif. 2010, 70, 116-121. [CrossRef] [PubMed]

139. Burda, M.R.; Miller, S. Folding of coliphage T4 short tail fiber in vitro. Analysing the role of a bacteriophage-encoded chaperone. Eur. J. Biochem. 1999, 265, 771-778. [CrossRef] [PubMed]

140. Hashemolhosseini, S.; Stierhof, Y.D.; Hindennach, I.; Henning, U. Characterization of the helper proteins for the assembly of tail fibers of coliphages T4 and lambda. J. Bacteriol. 1996, 178, 6258-6265. [CrossRef] [PubMed]

141. Herrmann, R.; Wood, W.B. Assembly of bacteriophage T4 tail fibers: Identification and characterization of the nonstructural protein gp57. Mol. Gen. Genet. 1981, 184, 125-132. [CrossRef] [PubMed]

142. Matsui, T.; Griniuviene, B.; Goldberg, E.; Tsugita, A.; Tanaka, N.; Arisaka, F. Isolation and characterization of a molecular chaperone, gp57A, of bacteriophage T4. J. Bacteriol. 1997, 179, 1846-1851. [CrossRef] [PubMed]

143. Leiman, P.G.; Arisaka, F.; van Raaij, M.J.; Kostyuchenko, V.A.; Aksyuk, A.A.; Kanamaru, S.; Rossmann, M.G. Morphogenesis of the T4 tail and tail fibers. Virol. J. 2010, 7, 355. [CrossRef]

144. Danner, M.; Fuchs, A.; Miller, S.; Seckler, R. Folding and assembly of phage P22 tailspike endorhamnosidase lacking the N-terminal, head-binding domain. Eur. J. Biochem. 1993, 215, 653-661. [CrossRef] 
145. Muhlenhoff, M.; Stummeyer, K.; Grove, M.; Sauerborn, M.; Gerardy-Schahn, R. Proteolytic processing and oligomerization of bacteriophage-derived endosialidases. J. Biol. Chem. 2003, 278, 12634-12644. [CrossRef]

146. Schulz, E.C.; Schwarzer, D.; Frank, M.; Stummeyer, K.; Muhlenhoff, M.; Dickmanns, A.; Gerardy-Schahn, R.; Ficner, R. Structural basis for the recognition and cleavage of polysialic acid by the bacteriophage $\mathrm{K} 1 \mathrm{~F}$ tailspike protein EndoNF. J. Mol. Biol. 2010, 397, 341-351. [CrossRef]

147. Xiang, Y.; Leiman, P.G.; Li, L.; Grimes, S.; Anderson, D.L.; Rossmann, M.G. Crystallographic insights into the autocatalytic assembly mechanism of a bacteriophage tail spike. Mol. Cell 2009, 34, 375-386. [CrossRef] [PubMed]

148. Thompson, J.E.; Pourhossein, M.; Waterhouse, A.; Hudson, T.; Goldrick, M.; Derrick, J.P.; Roberts, I.S. The K5 lyase KflA combines a viral tail spike structure with a bacterial polysaccharide lyase mechanism. J. Biol. Chem. 2010, 285, 23963-23969. [CrossRef] [PubMed]

149. Schulz, E.C.; Dickmanns, A.; Urlaub, H.; Schmitt, A.; Muhlenhoff, M.; Stummeyer, K.; Schwarzer, D.; Gerardy-Schahn, R.; Ficner, R. Crystal structure of an intramolecular chaperone mediating triple-beta-helix folding. Nat. Struct. Mol. Biol. 2010, 17, 210-215. [CrossRef] [PubMed]

150. Leiman, P.G.; Battisti, A.J.; Bowman, V.D.; Stummeyer, K.; Muhlenhoff, M.; Gerardy-Schahn, R.; Scholl, D.; Molineux, I.J. The structures of bacteriophages K1E and K1-5 explain processive degradation of polysaccharide capsules and evolution of new host specificities. J. Mol. Biol. 2007, 371, 836-849. [CrossRef]

151. Bartual, S.G.; Otero, J.M.; Garcia-Doval, C.; Llamas-Saiz, A.L.; Kahn, R.; Fox, G.C.; van Raaij, M.J. Structure of the bacteriophage T4 long tail fiber receptor-binding tip. Proc. Natl. Acad. Sci. USA 2010, 107, 20287-20292. [CrossRef]

152. Panchenko, A.R.; Luthey-Schulten, Z.; Cole, R.; Wolynes, P.G. The foldon universe: A survey of structural similarity and self-recognition of independently folding units. J. Mol. Biol. 1997, 272, 95-105. [CrossRef]

153. Maity, H.; Maity, M.; Krishna, M.M.; Mayne, L.; Englander, S.W. Protein folding: The stepwise assembly of foldon units. Proc. Natl. Acad. Sci. USA 2005, 102, 4741-4746. [CrossRef]

154. Miroshnikov, K.A.; Marusich, E.I.; Cerritelli, M.E.; Cheng, N.; Hyde, C.C.; Steven, A.C.; Mesyanzhinov, V.V. Engineering trimeric fibrous proteins based on bacteriophage T4 adhesins. Protein Eng. 1998, 11, 329-332. [CrossRef]

155. Miroshnikov, K.A.; Sernova, N.V.; Shneider, M.M.; Mesyanzhinov, V.V. Transformation of a fragment of beta-structural bacteriophage T4 adhesin to stable alpha-helical trimer. Biochemistry 2000, 65, 1346-1351.

156. Tao, Y.; Strelkov, S.V.; Mesyanzhinov, V.V.; Rossmann, M.G. Structure of bacteriophage T4 fibritin: A segmented coiled coil and the role of the C-terminal domain. Structure 1997, 5, 789-798. [CrossRef]

157. Chuprov-Netochin, R.N.; Faizullina, N.M.; Sykilinda, N.N.; Simakova, M.N.; Mesianzhinov, V.V.; Miroshnikov, K.A. The beta-helical domain of bacteriophage T4 controls the folding of the fragment of long tail fibers in a chimeric protein. Russ. J. Bioorg. Chem. 2010, 36, 172-178. [CrossRef] [PubMed]

158. Kanamaru, S.; Leiman, P.G.; Kostyuchenko, V.A.; Chipman, P.R.; Mesyanzhinov, V.V.; Arisaka, F.; Rossmann, M.G. Structure of the cell-puncturing device of bacteriophage T4. Nature 2002, 415, 553-557. [CrossRef] [PubMed]

159. Nakagawa, H.; Arisaka, F.; Ishii, S. Isolation and characterization of the bacteriophage T4 tail-associated lysozyme. J. Virol. 1985, 54, 460-466. [PubMed]

160. Mesyanzhinov, V.V.; Leiman, P.G.; Kostyuchenko, V.A.; Kurochkina, L.P.; Miroshnikov, K.A.; Sykilinda, N.N.; Shneider, M.M. Molecular architecture of bacteriophage T4. Biochemistry 2004, 69, 1190-1202. [CrossRef] [PubMed]

161. Scholz, C.; Eckert, B.; Hagn, F.; Schaarschmidt, P.; Balbach, J.; Schmid, F.X. SlyD proteins from different species exhibit high prolyl isomerase and chaperone activities. Biochemistry 2006, 45, 20-33. [CrossRef]

162. Chuprov-Netochin, R.N.; Amarantov, S.V.; Shneider, M.M.; Sykilinda, N.N.; Filchikov, M.V.; Ivanova, M.A.; Mesyanzhinov, V.V.; Miroshnikov, K.A. Peptidyl-prolyl isomerase SLyD controls the recombinant folding of bacteriophage T4 long tail fiber fragments. Russ. J. Biopharm. 2011, 3, 30-36.

163. Huys, I.; Pirnay, J.P.; Lavigne, R.; Jennes, S.; De Vos, D.; Casteels, M.; Verbeken, G. Paving a regulatory pathway for phage therapy. Europe should muster the resources to financially, technically and legally support the introduction of phage therapy. EMBO Rep. 2013, 14, 951-954. [CrossRef] 
164. Housby, J.N.; Mann, N.H. Phage therapy. Drug Discov. Today 2009, 14, 536-540. [CrossRef]

165. Summers, W.C. Bacteriophage therapy. Ann. Rev. Microbiol. 2001, 55, 437-451. [CrossRef]

(C) 2019 by the authors. Licensee MDPI, Basel, Switzerland. This article is an open access article distributed under the terms and conditions of the Creative Commons Attribution (CC BY) license (http://creativecommons.org/licenses/by/4.0/). 